\title{
Sun protection behaviors and its affecting factors in parents of kindergarteners
}

\author{
Anaokulunda çocuğu olan ebeveynlerin güneșten korunma davranıșları ve bunları \\ etkileyen faktörler
}

\section{Adem Sümen, ® Selma Öncel*}

\author{
Akdeniz University, Kumluca Faculty of Health Sciences, Department of Public Health Nursing, Antalya, Turkey
}

*Akdeniz University Faculty of Nursing, Department of Public Health Nursing, Antalya, Turkey

\begin{abstract}
Background and Design: Sunlight exposure during childhood is one of the main risk factors for skin cancer in adulthood. Therefore, one primary strategy to prevent skin cancer is to protect children from ultraviolet (UV) light. This study aimed to assess the risk level, perceptions, and knowledge level of skin cancer and the associated factors in parents of kindergarteners, as well as determine sun protection behaviors for both parents and their children.

Materials and Methods: This was designed as a cross-sectional study, and data were collected from the parents of children at 10 kindergartens associated with the District National Education Directorate. Parents of 1,147 students participated in the study.

Results: The Skin Cancer and Sun Knowledge Scale mean score of parents was 13.01 \pm 3.43 (range: 0-25) and the Sun Protection Behavior Scale mean score was $25.46 \pm 5.73$ (range: 8-40). The sun protection behaviors that were least preferred by parents for their children were protective clothes $(37.3 \%)$ and sun protection products $(29.0 \%)$. The most common protection behaviors of parents involved making their child wear a hat $(25.2 \%)$ and stay in the shade $(22.0 \%)$. Sun protection behaviors of children were affected by the child's age, gender, skin type, time spent in sunlight during summer, formation of sunburn during the last year, having a medical examination for skin, and skin cancer risk perception $(p<0.05)$.

Conclusion: The parents' knowledge about skin cancer and sun protection as well as sun protection for themselves and their children was moderate. Behaviors of parents are very important to decrease the exposure of children to UV light and reduce skin cancer incidence. Thus, improving parental behaviors is an important strategy.
\end{abstract}

Keywords: Skin neoplasms, sun protection factor, preschool, child, parents

\section{Öz}

Amaç: Çocukluk çağında güneş ışı̆̆ına maruziyeti, yetişkinlikte deri kanseri için ana risk faktörlerinden biridir. Bu yüzden deri kanserlerini önleme kampanyalarının ana hedeflerinden biri çocukları ultraviyole (UV) ışınlarından korumaktır. Bu çalışma, anaokulunda çocuğu olan ebeveynlerin deri kanseri ile ilgili risk düzeylerini, algılarını, bilgi düzeylerini ortaya çıkarmak ve bunları etkileyen faktörleri belirlemek amacıyla yapılmıştır. Ayrıca hem kendileri hem çocukları için uyguladıkları güneşten korunma davranışlarının belirlenmesi hedeflenmiştir.

Gereç ve Yöntem: Kesitsel tipteki bu araştırma, Illçe Milli Eğitim Müdürlüğü'ne bağlı 10 anaokulundaki çocukların ebeveynleri ile yürütülmüştür. Araştırmaya 1.147 öğrencinin ebeveyni katılmıştır.

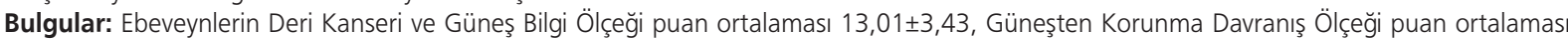

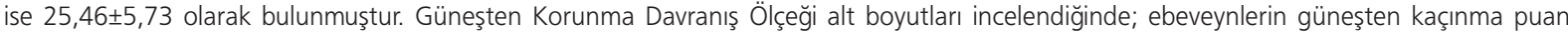

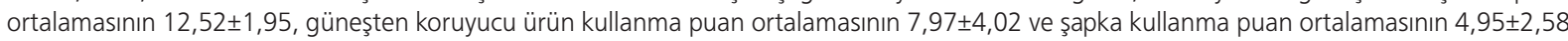

Address for Correspondence/Yazışma Adresi: Adem Sümen, Akdeniz University, Kumluca Faculty of Health Sciences, Department of Public Health Nursing, Antalya, Turkey

Phone: +90 5374695700 E-mail: ademsumen@akdeniz.edu.tr Received/Geliş Tarihi: 25.09.2020 Accepted/Kabul Tarihi: 09.05.2021 ORCID: orcid.org/0000-0002-8876-400X

Cite this article as: Sümen A, Öncel S. Sun protection behaviors and its affecting factors in parents of kindergarteners. Turkderm-Turk Arch Dermatol Venereol 2021;55:178-83 
olduğu belirlenmiştir. Ebeveynlerin çocukları için en az uyguladıkları güneşten korunma davranışı giysilerle (\%37,3) ve güneş koruyucu ürünlerle korumadır (\%29,0). En sık uyguladıkları koruma davranışı ise çocuklarının şapka takmalarını $(\% 25,2)$ ve gölgede durmalarını $(\% 22,0)$ sağlamalarıdır. Ebeveynlerin çocuklarını güneşten koruma davranışlarını çocuğunun yaşı, cinsiyeti, deri tipi, yaz mevsiminde açık alanda zaman geçirmesi, son bir yılda güneş yanığı oluşması, deri muayenesi yapması ve deri kanseri riski algısı düzeyinin etkilediği saptanmıştır $(p<0,05)$.

Sonuç: Ebeveynlerin deri kanseri ve güneşten korunma ile ilgili bilgi düzeyleri, kendilerine ve çocuklarına yönelik güneşten korunma davranışları orta düzeydedir. Deri kanseri insidansının azaltılmasında, çocuklarda UV ışığa maruz kalmayı azaltmak için güneșten korunmada ebeveyn davranışları çok önemli olup, doğru tutum ve davranışları artırmak önemli bir strateji olacaktır.

Anahtar Kelimeler: Deri neoplazmları, güneş koruyucu faktör, okul öncesi, çocuk, ebeveyn

\section{Introduction}

The sun is an indispensable organizer for the existence of biological life and the source of energy. Ultraviolet (UV) radiation arrives on the earth at higher levels than in the past and causes increasingly harmful effects because of ozone layer depletion. Therefore, the incidence of melanoma and other skin cancers is increasing daily ${ }^{1}$. Everyone is at risk for skin cancer; however, people who have light skin color, numerous nevus and spots, prolonged sun exposure, and a history of sunburn during childhood have a higher risk for skin cancer ${ }^{2}$. The popularity of tanning, the psychological effect of looking beautiful, and the activities on vacations increase the effects of UV radiation on human health ${ }^{3}$. The discovery of the link between exposure to heavy UV radiation during childhood and skin cancer, especially melanoma, allowed us to understand the importance of daily practice from childhood ${ }^{4}$. Sun protection should be advised for all children regardless of skin phototype. Regular sun protection during childhood and adolescence reduces the lifetime incidence of skin cancer. Habits are most easily formed in childhood, thus appropriate sun protection practices should be taught to children through different trainings $\mathrm{s}^{4,5}$.

Children do not know the harmful effects of the sun. Therefore, parental behaviors are important for sun protection in children, and parental attitudes and parents are the first role models for their children ${ }^{68}$. Many studies emphasize that parents should be focused on groups for changing sun protection behaviors of children to prevent skin cancer ${ }^{9-11}$. Family nurses have important roles in the early diagnosis and prevention of skin cancer. They teach children and their parents about sun protection and its importance. Awareness about sun protection is extremely important to occur early in life, together with appropriate parental training because sun exposure is experienced particularly in childhood ${ }^{12}$. Thus, peer interactions in school during childhood should be guided to raise awareness, and school nurses should provide training regarding sun exposure and protective behaviors ${ }^{13}$.

There are three target groups in kindergartens: Students, teachers, and parents. Healthcare providers should cooperate with teachers and parents, and they should allow children to develop the desired knowledge, attitudes, behaviors, and values about health both in and outside the classroom. This study aimed to determine the sun protection behaviors and the affecting factors of the parents with kindergarteners both for themselves and their children and form a basis for sun protection programs for children by asking the following research questions:

- How do the parents perceive the risk of skin cancer for themselves and their children?

- What are the skin cancer risk levels of parents and their children?

- What are the knowledge levels of parents regarding skin cancer and sun protection?
- What are the sun protection behaviors of parents for themselves? - What are the sun protection behaviors of parents for their children?

- What are the factors that affect the sun protection behaviors of parents for their children?

\section{Materials and Methods}

\section{Design and participants}

This study uses a cross-sectional survey design and was carried out in the Mediterranean region in a province located by the sea during the spring semester of the 2016-2017 academic year. The focus of the study consisted of the parents of children at 10 kindergartens associated with the District National Education Directorate. A sampling method was not used in the study, and volunteer parents of 1,147 students were included.

The study protocol was approved by Akdeniz University Faculty of Medicine Clinical Research Ethics Committee (approval number: 190, date: 22/03/2017). Informed consent was obtained from all individual participants included in the study.

\section{Instruments}

The data was collected using a Parental Information Form, The Fitzpatrick Skin Type Scale, Skin Cancer and Sun Knowledge Scale (SCSKS), Sun Protection Behavior Scale (SPBS), Child Information Form, and questions about Sun Protection Applications of Parents.

The Parental Information Form included 12 questions including demographic questions (age, gender, educational background, income status, and familial history of skin cancer), sun exposure, and sunburn formation.

The Fitzpatrick Skin Type Scale is a numerical classification schema in which skin color is categorized into six types based on the tendency of skin to develop sunburn through exposure to UV, complexion, hair, and eye color. According to the Fitzpatrick skin type classification, melanin content of the skin gradually decreases from type 6 to type 1, and the tendency to develop skin cancer increases as a result of sensitivity to UV damage. Those with skin types 1 and 2 have high, 3 and 4 have moderate, and 5 and 6 have a low risk of developing skin cancer ${ }^{14}$.

The SCSKS consists of 25 items and evaluates the information about five fields: The indications of sun protection, sun tanning, skin cancer risk factors, skin cancer prevention, and skin cancer. The items consist of 15 correct-incorrect and 10 multiple-choice questions. For each item, correct answers are symbolized by (1) and incorrect by (0). Total points are $0-25$ on the scale. The higher the score obtained, the higher the knowledge level. The Turkish validity and reliability of the SCSKS were measured by Haney et al. ${ }^{15}$ using university students in a nursing department. The content validity index of SCSKS was $93.71 \%$ and the internal consistency reliability coefficient was (KR-20) $0.51^{15}$. 
The SPBS was used in adult intervention studies. Turkish validity and reliability of the scale were measured by Aygun and Ergun ${ }^{16}$. It is a five-point Likert-type scale consisting of eight items that are used to measure the frequency of sun protection behaviors for times spent outside for $>15$ min with the scales never (1 point), rarely ( 2 points), sometimes (3 points), mostly (4 points), and always (5 points). A score ranging from 8 to 40 can be obtained. The Cronbach's alpha value of the scale was 0.74 . The scale has three sub-dimensions: Avoiding sun exposure $(\alpha=0.67)$, using sun protection $(\alpha=0.88)$, and using a hat $(\alpha=0.70)$. A score range of 3-15 can be obtained from avoiding sun exposure and using sun protection sub-dimensions and a score range of 2-10 can be obtained from the sub-dimension using a hat. An increased score indicates highly protective behavior ${ }^{16}$.

The Child Information Form and Sun Protection Applications of Parents includes seven questions regarding the child's age, gender, skin type, Fitzpatrick skin type scale for determining skin type, sun exposure and sunburn formation, and sun protection behaviors of the parents for their children (sunscreen, long-sleeved clothes, staying in the shade, hats, and sunglasses) $)^{6,8-11,17}$. Responses given for the sun protection applications varied between "never" and "always" on a 5-point scale. A high score shows high sun protection behaviors of parents for their children.

\section{Statistical Analysis}

Statistical analyzes of the data were made using the SPSS Statistics Base $V 23$ version of the SPSS software licensed from our institution. Descriptive statistical methods were used to evaluate the data (frequency, percentage, mean, and standard deviation), the t-test and One-Way analysis of variance was used for independent variables to test for differences between the groups, and the Tukey and Hochberg tests were used for dependent variables to determine differences between the groups. Results were evaluated at a confidence interval of $95 \%$ and with a significance level of $p<0.05$.

\section{Results}

Of the parents participating in the study, $79.7 \%$ were female and the mean age was $34.41 \pm 5.95$ years, wherein $45.2 \%$ were housewives, $39.2 \%$ graduated from high school, $32.0 \%$ graduated from a university, and $55.1 \%$ stated that their income matched their expenses. Of the parents, $37.1 \%$ stated they stayed in the sun for approximately 2 hours or more between 10.00 AM and 4.00 PM in the summer, 5.3\% experienced at least one red, water-gathering, blistered, or painful sunburn a year, and $11.8 \%$ spent two or more hours in the sun to tan. Family skin cancer history was found in $1.8 \%$ of the parents and nearly all (94\%) did not do self-skin examinations. While $35.0 \%$ of parents reported they had previous information about the subject, $15.4 \%$ did not think about sun protection, $24.9 \%$ did not have enough information, and $39.6 \%$ did not implement protective measures even though they had enough information.

For the kindergarteners, $52.2 \%$ were female and the mean age was $5.17 \pm 0.80$ years. The parents stated that $23.8 \%$ of the children stayed in the sun for approximately 2 hours or more between $10.00 \mathrm{AM}$ and $4.00 \mathrm{PM}$ in the summer and $4.4 \%$ experienced at least one red, watergathering, blistered, or painful sunburn a year.
Skin type of 2 and high risk for skin cancer was found in 3.0\% of the parents and $7.7 \%$ of the children, whereas $79.2 \%$ of the parents and $82.1 \%$ of the children had a skin type of 3-4 and an intermediate risk, and $17.9 \%$ of the parents and $10.2 \%$ of the children had a skin type of 5-6 and were at low risk for skin cancer. Nearly half of the parents considered themselves (47.2\%) and their children (41.3\%) not at risk for skin cancer. Of the parents, 39.3\% considered themselves at low risk and $10.6 \%$ at intermediate risk, whereas $43.0 \%$ considered their children at low risk, 3.8\% at intermediate risk, and 1.9\% at high risk (Table 1).

The SCSKS mean score of parents was 13.01 \pm 3.43 (minimummaximum: 3-21), whereas the SPBS mean score was $25.46 \pm 5.73$ (minimum-maximum: 13-40). The SPBS sub-dimensions analyses revealed that a mean score of $12.52 \pm 1.95$ (minimum-maximum: 6-15) the parents' sun avoidance, sun protection products use was $7.97 \pm 4.02$ (minimum-maximum: 3-15), and hat use was $4.95 \pm 2.58$ (minimum-maximum: 2-10) (Table 2). The least applied sun protection behavior (answered with never) of the parents for their children was protective clothes (37.3\%) and sun protection products (29.0\%), and the most applied sun protection behavior (answered with always) was hat use (25.2\%) and staying in the shade (22.0\%) (Table 3).

Table 1. Distribution of skin cancer risk levels and risk perceptions of parents and their children $(n=1147)$

\begin{tabular}{|l|l|l|}
\multirow{2}{*}{ Characteristics } & Parents & Children \\
\cline { 2 - 3 } & $\mathbf{n}(\%)$ & $\mathbf{n}(\%)$ \\
\hline Skin type & $34(3.0)$ & $88(7.7)$ \\
\hline Skin type 2 & $425(37.1)$ & $466(40.6)$ \\
\hline Skin type 3 & $483(42.1)$ & $476(41.5)$ \\
\hline Skin type 4 & $205(17.8)$ & $113(9.9)$ \\
\hline Skin type 5 & - & $4(0.3)$ \\
\hline Skin type 6 & \multicolumn{2}{|l}{} \\
\hline Risk of getting skin cancer & $541(47.2)$ & $474(41.3)$ \\
\hline Does not see self/child at risk & $451(39.3)$ & $493(43.0)$ \\
\hline Sees self/child at low risk & $122(10.6)$ & $158(13.8)$ \\
\hline Sees self/child at moderate risk & $33(2.9)$ & $22(1.9)$ \\
\hline Sees self/child at high risk &
\end{tabular}

Table 2. Parents' mean scores on the Skin Cancer and Sun Knowledge Scale and the Sun Protection Behavior Scale and subdimensions $(n=1147)$

\begin{tabular}{|l|l|l|l|l|}
\hline Scales & $\begin{array}{l}\text { Score } \\
\text { range }\end{array}$ & Minimum & Maximum & $\begin{array}{l}\text { Mean } \\
\text { (SD) }\end{array}$ \\
\hline $\begin{array}{l}\text { Skin Cancer and Sun } \\
\text { Knowledge Scale }\end{array}$ & $0-25$ & 3 & 21 & $\begin{array}{l}13.01 \\
(3.43)\end{array}$ \\
\hline $\begin{array}{l}\text { Sun Protection } \\
\text { Behavior Scale }\end{array}$ & $8-40$ & 13 & 40 & $\begin{array}{l}25.46 \\
(5.73)\end{array}$ \\
\hline Avoiding the sun & $3-15$ & 6 & 15 & $\begin{array}{l}12.52 \\
(1.95)\end{array}$ \\
\hline Using sunscreen & $3-15$ & 3 & 15 & $\begin{array}{l}7.97 \\
(4.02)\end{array}$ \\
\hline Using a hat & $2-10$ & 2 & 10 & $\begin{array}{l}4.95 \\
(2.58)\end{array}$ \\
\hline SD: Standard deviation & & \multicolumn{5}{|l}{} \\
\hline
\end{tabular}




\begin{tabular}{|l|l|l|l|l|l|}
\hline Table 3. Distribution of sun protection behaviors of parents for their children $(\mathbf{n = 1 1 4 7 )}$ & Never & Rarely & Sometimes & Often & Always \\
\hline Behavior, $\mathbf{n}(\%)$ & $333(29.0)$ & $232(20.2)$ & $205(17.9)$ & $272(23.7)$ & $105(9.2)$ \\
\hline Protection with sunscreen products & $34(3.0)$ & $124(10.8)$ & $259(22.6)$ & $440(38.4)$ & $290(25.2)$ \\
\hline Protection with hat & $428(37.3)$ & $256(22.3)$ & $363(31.6)$ & $86(7.5)$ & $14(1.2)$ \\
\hline Protection with clothes & $271(23.6)$ & $172(15.0)$ & $314(27.4)$ & $255(22.2)$ & $135(11.8)$ \\
\hline Protection with sunglasses & $33(2.9)$ & $89(7.8)$ & $173(15.1)$ & $600(52.2)$ & $252(22.0)$ \\
\hline Protection by staying in the shade & & & & \\
\hline
\end{tabular}

Table 4. Mean scores of the comparison of parents' sun protection behaviors for their children with some characteristics of their children $(n=1147)$

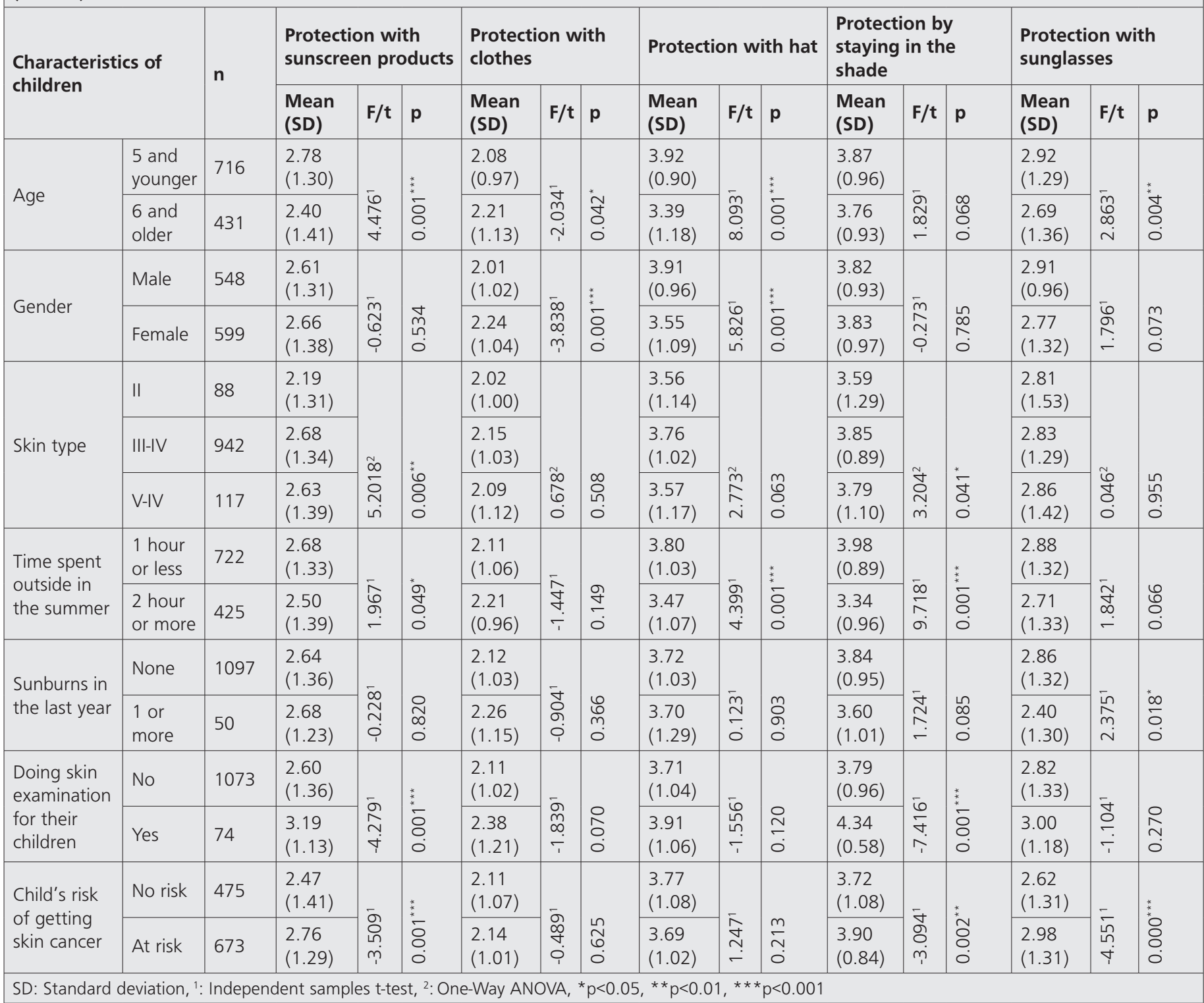

When sun protection behaviors of parents were investigated based on some children characteristics, sun protection products were preferred by parents who had a child aged 5 years and younger $(p<0.001)$, with Fitzpatrick's skin types 3-6 ( $p<0.01)$, and who spent one hour or less in the sun during the summer $(p<0.05)$ and parents who did skin examinations on the child $(p<0.01)$ or saw their children as at risk for skin cancer $(p<0.001)$. Protection with clothes was preferred by parents who had a child aged 6 years or older $(p<0.05)$ or had a daughter $(p<0.001)$. Protection with a hat was preferred by parents with a child aged 5 years and younger $(p<0.001)$, had a son $(p<0.001)$ or had a child who spent one hour or less in the sun during the summer $(p<0.001)$. Protection with sunglasses was preferred by the parents with a child aged 5 years and younger $(p<0.01)$, a child who did not have a sunburn during the last year $(p<0.05)$, or who saw their children as at risk for skin cancer $(p<0.001)$. Protection by staying in the shade was preferred by parents whose children had Fitzpatrick's skin types 
3-6 $(p<0.01)$ and spent one hour or less in the sun during the summer $(p<0.001)$, who performed skin examination on the child $(p<0.001)$, or who saw their children as at risk for skin cancer $(p<0.01)$ (Table 4).

\section{Discussion}

Children receive more exposure to UV lights than adults because of school activities and games during the first 18 years of their life. Children have thinner and more sensitive skin than adults and are more affected by sunlight when outside in the hot sun ${ }^{18}$. Children who are more exposed to sunlight are at risk for future skin cancer ${ }^{12}$. The risk of melanoma doubles for those having light eye color (blue/green) or colored hair (yellow/crimson), developing sunburn easily, tending to be freckled and cannot tan, and having Fitzpatrick skin types of $1-2^{19}$. The number of parents and children having such skin types was limited in this study. The number of children at high risk was greater than the number of adults, and this gives important clues for possible risks. Parents are in the high-risk skin type group; however, their risk perception is approximately half of the actual rate for themselves and their children. This finding is important since it shows that parents were not as aware as they should have been. Parents in this group should protect both themselves and their children. Therefore, training and informing the groups at risk is necessary for them to develop protective behaviors ${ }^{6,20,21}$.

Parents' knowledge scores about skin cancer and sun protection were moderate. However, this knowledge level is inadequate because the maximum score was 21 out of 25 on the scale and the least known questions relate to sun protection, tanning, and skin cancer risk factors. The knowledge level of parents was similar to many other studies that were previously conducted ${ }^{20,22}$. A systematic review including 31 studies conducted in the Turkish community on skin cancer and sun protection inferred that individuals' awareness regarding sun protection should be improved ${ }^{23}$. The sun avoidance behavior of parents was high, whereas the sun protection and hat use behaviors were at moderate levels. The literature shows that the use of hats and sunscreen is low when parents go out during the day $21,24,25$. Individuals are more apt to avoid the sun than to utilize sun protection behaviors. This may be because physical methods, such as wearing a hat, glasses, and sun protection products, are more difficult to practice.

Parents showing similar behaviors when protecting themselves and their children is important because it shows the implementation of their knowledge. Children learn about different behaviors and skills throughout their development. They feel the support of their parents to cope with difficulties during childhood ${ }^{26}$. The most widely used applications for protecting children against harmful sun lights were to let them stay in the shade and use a hat, sunglasses, sun protection products, and clothes. Other studies conducted in Turkey support those findings ${ }^{23}$. One study showed that except for protection with sunglasses, parents protect their children more than themselves using a hat, sun protection products, and clothes ${ }^{27}$. Two studies conducted showed that parents preferred to ensure protection with a hat, sun protection products, clothes, sunglasses, and staying in the shade ${ }^{17,19}$. Behaviors of parents are important for protecting their children against the sun due to the impact of the exposed sunlight on skin cancer development. Thus, parents could be positive role models for their children with their attitudes and behaviors ${ }^{10,28}$.
The child's age is important for sun protection behaviors of parents for their children; furthermore, protection behaviors beyond protective clothes increase as age goes down. Some research indicates that protection with clothes decreases as age increases in children 7,17,21. An increased autonomy with age, children's developmental features, and their efforts to choose their clothes is believed to affect this subject. Similar to the self-protection behaviors of adults, protection with clothes in girls ${ }^{29}$ and protection with hats in boys ${ }^{30}$ is more common. The protection behaviors of parents whose children spend 2 hours or more in the sun during the summer were significantly lower in using sun protection products, hats, and staying in the shade. Children are more sensitive to radiation damage from UV lights and have thinner and more sensitive skin than adults. Having high exposure to sun lights in childhood plays a role in skin cancer and eye damage and suppresses the immune system ${ }^{5,19}$. Thus, children should be taught behaviors to protect themselves against sun lights and develop self-protection behaviors at an early age. Parents whose children did not have sunburn during the last year had the positive behavior depicted by a high score for wearing a hat and low scores for the other four behaviors, which show that they were not conscious enough. Therefore, they need to take additional actions to provide efficient sunlight protection. The melanin content in the skin from 6 to 1 in the Fitzpatrick skin types decreases gradually, whereas sensitivity to sunburn and tendency for skin cancer increases gradually ${ }^{14}$. Parents were expected to better protect their children with skin type 2 based on risk level; however, they had lower protection behaviors than expected using only sun protection products and staying in the shade. Developing protection behaviors for their children more than themselves with sun protection products, sunglasses, and staying in the shade is a positive attitude of parents with children at a higher risk of skin cancer. Little children learn by imitation and parents should consciously support this learning ${ }^{13}$. Furthermore, parents should utilize self-protection from the sun for themselves to become role models for their children.

\section{Study Limitations}

A long-period design model shall reinforce the validity of the variables. Parents might have answered the questions thinking acceptability on sun protection and protecting their children from the sun, as the data collected were based on statements/declarations of individuals.

\section{Conclusion}

Five out six parents and nine out of ten children were found to be at moderate or high risk for skin cancer based on skin type. Nearly half of the parents (47.2\%) considered themselves and their children (41.3\%) not at risk for skin cancer. Parents had a moderate level of knowledge regarding skin cancer and sun protection, but they exhibited a high level of avoidance behaviors and a moderate level of sun protection and hat use. The most common protection behaviors of the parents for their children were staying in the shade and protection using hats or sunglasses, sun protection products, and clothes.

Therefore, the parents' knowledge about skin cancer and sun protection as well as their sun protection behaviors for themselves and their children are at a moderate level. The following can be suggested: - Parents become role models for their children with their attitudes 
and behaviors because parental behaviors are important for protecting children from sunlight.

- The skin type of kindergarteners and their risk levels should be determined, and parents should be informed.

- Parents should be informed about how to protect their children from sunlight during childhood.

- The schools and non-formal education institutions should provide educational programs about this subject.

\section{Ethics}

Ethics Committee Approval: The study protocol was approved by Akdeniz University Faculty of Medicine Clinical Research Ethics Committee (approval number: 190, date: 22/03/2017).

Informed Consent: Informed consent was obtained from all individual participants included in the study.

Peer-review: Externally and internally peer-reviewed.

\section{Authorship Contributions}

Concept: A.S., S.Ö., Design: A.S., S.Ö., Data Collection or Processing: A.S., Analysis or Interpretation: A.S., S.Ö., Literature Search: A.S., S.Ö., Writing: A.S., S.Ö.

Conflict of Interest: No conflict of interest was declared by the authors.

Financial Disclosure: The authors declared that this study received no financial support.

\section{References}

1. Vogel RI, Strayer LG, Engelman L, et al.: Sun exposure and protection behaviors among long-term melanoma survivors and population controls. Cancer Epidemiol Biomarkers Prev 2017;26:607-13.

2. Lai V, Cranwell W, Sinclair R: Epidemiology of skin cancer in the mature patient. Clin Dermatol 2018;36:167-76.

3. Jiang $A J$, Rambhatla PV, Eide MJ: Socioeconomic and lifestyle factors and melanoma: A systematic review. Br J Dermatol 2015;172:885-915.

4. Carretier J, Boyle H, Duval S, et al.: A review of health behaviors in childhood and adolescent cancer survivors: toward prevention of second primary cancer. J Adolesc Young Adult Oncol 2016;5:78-90.

5. Gilaberte $Y$, Carrascosa JM: Sun protection in children: realities and challenges. Actas Dermosifiliog 2014;105:253-62.

6. Hamilton K, Cleary C, White KM, Hawkes AL: Keeping kids sun safe: exploring parents' beliefs about their young child's sun-protective behaviours Psychooncology 2016;25:158-63.

7. Hamilton K, Kirkpatrick A, Rebar A, Hagger MS: Child sun safety: Application of an Integrated Behavior Change model. Health Psychol 2017;36:916-26.

8. Kunene Z, Albers PN, Lucas RM, Banwell C, Mathee A, Wright CY: 'My child did not like using sun protection': practices and perceptions of child sun protection among rural black African mothers. BMC Public Health 2017; 17:677.

9. Glanz K, Steffen AD, Schoenfeld E, Tappe KA: Randomized trial of tailored skin cancer prevention for children: the Project SCAPE family study. J Health Commun 2013;18:1368-83.
10. Bodekær LM, Petersen B, Philipsen PA, et al.: Sun exposure and protection behavior of Danish farm children: parental influence on their children. Photochem Photobiol 2014;90:1193-8.

11. Stöver LA, Hinrichs B, Petzold $U$, et al.: Getting in early: primary skin cancer prevention at 55 German kindergartens. $\mathrm{Br}$ J Dermatol 2012;167(Suppl2):63-9

12. Saraiya M, Glanz K, Briss PA, et al.: Interventions to prevent skin cancer by reducing exposure to ultraviolet radiation: a systematic review. Am J Prev Med 2004:27:422-66.

13. Sümen A, Öncel S: Development of sun protection behaviors in preschoolers: A systematic review. Turkderm-Turk Arch Dermatol Venereology 2018;52:5663.

14. Fitzpatrick TB: The validity and practicality of sunreactive skin types I thorugh VI. Arch Dermatol 1998;124:869-71.

15. Haney MO, Bahar Z, Beser A, Arkan G, Cengiz B: Psychometric testing of the Turkish version of the skin cancer and sun knowledge scale in nursing students. J Cancer Educ 2018;33:21-8.

16. Aygun $\mathrm{O}$, Ergun A: Validity and reliability of sun protection behavior scale among Turkish adolescent population. Asian Nurs Res 2015;9:235-42.

17. Wan M, Hu R, Li Y, et al.: Attitudes, beliefs, and measures taken by parents to protect their children from the sun in Guangzhou City, China. Photochem Photobiol 2016:92:753-9.

18. Green AC, Wallingford SC, McBride P: Childhood exposure to ultraviolet radiation and harmful skin effects: Epidemiological evidence. Prog Biophys Mol Bio 2011;107:349-55

19. Tan MG, Nag S, Weinstein M: Parental use of sun protection for their children-does skin color matter?. Pediatr Dermatol 2018;35:220-4

20. Gefeller O, Uter W, Pfahlberg AB: Protection from Ultraviolet Radiation during Childhood: The Parental Perspective in Bavaria. Int J Environ Res Public Health 2016;13:1011

21. Day AK, Stapleton JL, Natale-Pereira AM, Goydos JS, Coups EJ: Parent and child characteristics associated with child sunburn and sun protection among US Hispanics. Pediatr Dermatol 2017;34:315-21.

22. Johnson K, Davy L, Boyett T, Weathers L, Roetzheim RG: Sun protection practices for children: knowledge, attitudes, and parent behaviors. Arch Pediatr Adolesc Med 2011;155:891-6.

23. Sümen $A$, Öncel $S$ : Investigation of the research on skin cancer and sun protection in Turkey. Turkiye Klinikleri J Nurs Sci 2018;10:59-69.

24. Klostermann S, Fromme H, Bolte G; für die GME Studiengruppe. Is there an Association between Prevention Campaign Knowledge and Sun Protection Behaviour of Parents for their Children? Results of a Parent Survey. Gesundheitswesen 2015;77:436-8.

25. Ho BK, Reidy K, Huerta I, et al.: Effectiveness of a multicomponent sun protection program for young children: a randomized clinical trial. JAMA Pediatr 2016;170:334-42.

26. Phillips DA, Lowenstein AE: Early care, education, and child development. Annu Rev Psychol 2011;62:483-500.

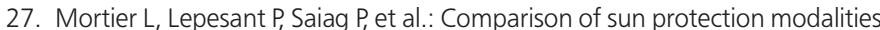
in parents and children. J Eur Acad Dermatol Venereol 2015;29(Suppl2):16-9.

28. Sümen A, Öncel S: Studies conducted with students about skin cancer and sun protection: a literature review. DEUHYO ED 2014;7:78-91.

29. Hillhouse J, Turrisi R, Jaccard J, Robinson J: Accuracy of self-reported sun exposure and sun protection behavior. Prev Sci 2012;13:519-31.

30. Wickenheiser M, Baker MK, Gaber R, Blatt H, Robinson JK: Sun protection preferences and behaviors among young adult males during maximum ultraviolet radiation exposure activities. Int J Environ Res Public Health 2013:10:3203-16 